\title{
Biochemical Evaluation and Out Come of Hepatitis E in Pregnancy
}

Fazle Rabbi Mohammed ${ }^{1}$, Raihana Amin², H A M Nazmul Ahasan³, Md Billal Alam ${ }^{4}$

\begin{abstract}
:
Background: Viral hepatitis is common in Bangladesh. Hepatitis E virus is waterborne and usually self-limiting. But infection with Hepatitis E virus is a serious threat to pregnancy. In this study, we aimed to assess the clinical course and biochemical evaluation of hepatitis E during pregnancy.
\end{abstract}

Materials \& Methods: This descriptive observational study included 50 pregnant women having hepatitis E conducted from September, 2008 to September, 2011 in Dhaka Medical College Hospital. Every case was initially evaluated on the basis of history, clinical examination, liver function profile and serological test of hepatitis $E$.

Result: Anti HEV IgM was detected in each case. Most of them (64\%) were in third trimester and only $42 \%$ cases got boiled water. The mean value of serum bilirubin, alanine aminotransferase (ALT) and prothrombin time (PT) was 11.62 $\mathrm{mg} / \mathrm{dl} \pm 8.01 \mathrm{SD}, 777.75 \mathrm{U} / \mathrm{L} \pm 590.39 \mathrm{SD}$ and $29.88 \mathrm{sec} \pm 12.54 \mathrm{SD}$ respectively. Acute hepatic failure (AHF) was detected in $56 \%$ pregnant women. In this study, the death rate of Hepatitis E in pregnancy was $43 \%$.

Conclusion: During pregnancy, hepatitis $E$ is associated with the development of acute hepatic failure (AHF) which has high mortality rate.

Keywords: Hepatitis E, Pregnancy, Hepatic failure.

\section{Introduction:}

Hepatitis $\mathrm{E}$ virus (HEV) infection is the most frequent cause of acute viral hepatitis (AVH) in developing countries recognized first in the Indian subcontinent in the $1950 \mathrm{~s} .{ }^{1}$ The disease is usually self-limited with a very low fatality rate in non-pregnant women. But infection with HEV is a serious threat to pregnancy. The incidence of fulminant hepatic failure (FHF) in pregnancy due to hepatitis $\mathrm{E}$ is significantly higher with a mortality rate up to $20 \%$ in endemic areas. ${ }^{2}$ The interesting and variable clinical course of HEV in pregnancy is associated with an altered status of sex steroid hormones, immunity and folate deficiency. ${ }^{3}$ Outbreaks of $\mathrm{HEV}$ are observed regularly in Bangladesh particularly in urban areas where water supply is seriously compromised due to over burden of population. ${ }^{4}$ In this study, we aimed to assess the clinical course and biochemical evaluation of hepatitis $\mathrm{E}$ during pregnancy.

\section{Materials and methods:}

This descriptive observational study included 50 pregnant women having hepatitis E conducted from September, 2008 to September, 2011 in Dhaka Medical College Hospital. They were classified into three groups depends on gestational age. Patients were distributed according to their occupation,

1. Dr. Fazle Rabbi Mohammed, MBBS, MD, Specialist, Department of Respiratory Medicine, Square Hospitals Ltd, Dhaka, Bangladesh.

2. Dr. Raihana Amin, MBBS, FCPS, Assistant Professor, Department of Obst \& Gynae, Dhaka Community Medical College Hospital, Dhaka.

3. Profesoor Dr. H A M Nazmul Ahasan, MBBS, FCPS, FRCP, FACP, Professor \& head, Department of Medicine, Dhaka Medical College \& Hospital, Dhaka, Bangladesh.

4. Professor Dr. Md Billal Alam, MBBS, FCPS, MD, Professor, Department of Medicine, Dhaka Medical College \& Hospital, Dhaka.

\section{Corresponding Author:}

Dr. Fazle Rabbi Mohammed, MBBS, MD, Specialist, Department of Respiratory Medicine, Square Hospitals Ltd, Dhaka, Bangladesh.. E-mail: rabbimd@gmail.com monthly income and residential status. Source of drinking water was also taken in account to find out a possible source of transmission. Every case was initially evaluated on the basis of history, clinical examination, liver function profile, and serological test of hepatitis E. The blood samples were screened using commercially available ELISA kits for markers of hepatitis E (EIAgen HEV IgM, Adaltis).These ELISA kit had a sensitivity of $100 \%$ and specificity of $\geq$ $99.5 \%$. Serum bilirubin was measured using colorimetric method DMSO (Chronolab). ALT estimation was done by UV- Kinetic (IFCC) method (Chronolab). Prothrombin time was measured using Neoplastine CI Plus (rabbit brain thromboplastine) reagent in an automated instrument which used an optical detection. Consent was taken in each case and ethical clearance was sought from proper authority. Data were collected in a preformed questionnaire and face-to-face interview was carried out. Data were analyzed in SPSS 15.

\section{Result:}

Most of the patients (64\%) were in third trimester and remaining 36\% were in second trimester. Only $42 \%$ cases got boiled water; remaining 58\% used to drink unpurified water from different sources. Most of them were house wife (76\%); $63 \%$ came from urban areas and remaining from slum, rural or semi urban areas. Forty six percent patients had a monthly income less than five thousand taka.

All of the patients presented with different prodromal symptoms, 27\% complaint right upper abdominal pain.

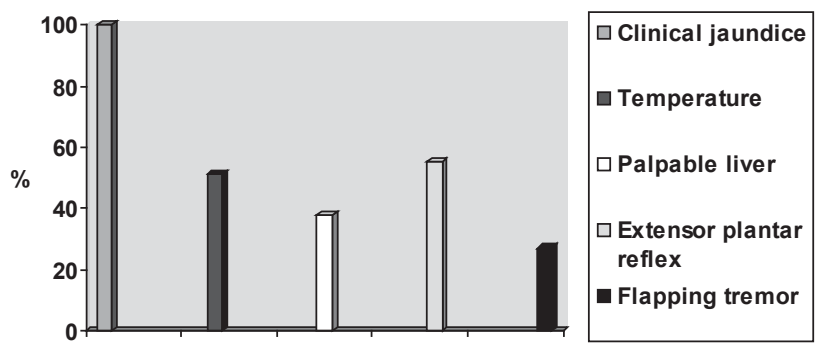

Fig I: Baseline clinical findings of the patients $(n=50)$. 
At the time of examination, all of them had clinically detectable jaundice, $51 \%$ had temperature $\geq 99^{\circ} \mathrm{F}$ and $38 \%$ had palpable liver. Clinically $78 \%$ patients were deep to moderately icteric. Extensor plantar reflex was present in $55 \%$ cases and $27 \%$ had flapping tremor. (Fig I) Anti HEV $\operatorname{IgM}$ was detected in each case.

\begin{tabular}{|l|l|l|l|}
\hline Value & $\begin{array}{l}\text { S. Bilirubin } \\
(\mathrm{mg} / \mathrm{dl})\end{array}$ & $\begin{array}{l}\text { ALT } \\
(\mathrm{U} / \mathrm{L})\end{array}$ & $\begin{array}{l}\text { PT } \\
(\mathrm{sec})\end{array}$ \\
\hline Mean \pm SD & $\begin{array}{l}11.62 \pm \\
8.01\end{array}$ & $\begin{array}{l}777.75 \pm \\
590.39\end{array}$ & $\begin{array}{l}29.88 \pm \\
12.54\end{array}$ \\
\hline Highest & 34 & 1870 & 56 \\
\hline Lowest & 3.2 & 33 & 13 \\
\hline
\end{tabular}

Table I: Report of different biochemical investigations in patients $(\mathrm{n}=50)$.

In this study, the mean value of serum bilirubin, alanine aminotransferase (ALT) and prothrombin time (PT) was $11.62 \mathrm{mg} / \mathrm{dl} \pm 8.01 \mathrm{SD}, 777.75 \mathrm{U} / \mathrm{L} \pm 590.39 \mathrm{SD}$ and $29.88 \mathrm{sec}$ $\pm 12.54 \mathrm{SD}$ respectively. The highest values of serum bilirubin, ALT and PT of patients were $34 \mathrm{mg} / \mathrm{dl}, 1870 \mathrm{U} / \mathrm{L}$ and 56 second respectively and the lowest values of serum bilirubin, ALT and PT of patients were $3.2 \mathrm{mg} / \mathrm{dl}, 33 \mathrm{U} / \mathrm{L}$ and 13 second respectively. (Table I)
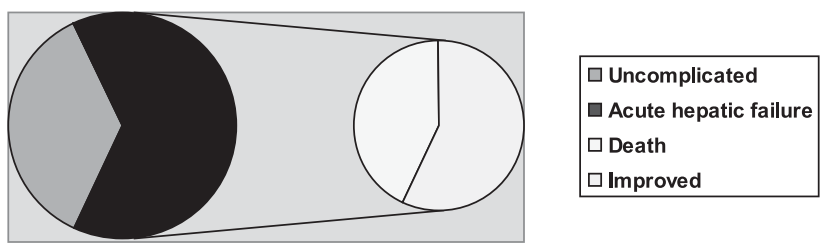

Fig II: Distribution of cases according to the complication and outcome $(\mathrm{n}=50)$.

Acute hepatic failure (AHF) was detected in 56\% pregnant women. In this study, the death rate of Hepatitis $\mathrm{E}$ in pregnancy was $43 \%$. (Fig II)

\section{Discussion:}

HEV is transmitted by faeco-oral route. Major outbreaks of HEV are related with contaminated water or food supplies. Epidemics of hepatitis E have been reported in Central and South-East Asia, North and West Africa, and in Mexico, especially where faecal contamination of drinking water is common. Occasionally, FHF develops, with overall patient population mortality rates ranging between $0.5 \%-4.0 \% .{ }^{5}$ But a significant proportion of pregnant women can progress to fulminant hepatitis particularly in the third trimester, with a mortality rate varying from 30 to $100 \%{ }^{6-14}$ A significant geographical distribution of FHF and fatal outcome in pregnancy with HEV was detected. Reports from Egypt, Europe and the USA have shown that the course and severity of viral hepatitis during pregnancy is not different from that in non-pregnant women. More studies are awaited to reveal this strange cause. The high mortality rate in pregnancy has been thought to be secondary to the associated hormonal (oestrogen and progesterone) changes during pregnancy and consequent immunological changes. ${ }^{15}$
In this study, 64\% women were in third trimester of pregnancy and remaining $36 \%$ were in second trimester. A study in Ghana found that HEV detected in women in their third trimester of pregnancy $(80 \%)$ was significantly higher than in women in their second trimester of pregnancy (20\%). Total 45 pregnant women with HEV were described in that study. ${ }^{16}$ Another study conducted in Kashmir, India revealed the rate of HEV in pregnancy was $8.8 \%, 19.4 \%$ and $18.6 \%$ in first trimester, second trimester and third trimester respectively. ${ }^{17}$

In this country, many women worked in densely populated unhygienic environment with very poor sanitation facilities. In this study, most of the pregnant women (58\%) used to drink unpurified water from different sources and $76 \%$ were involved in house bound activities. Most of the women included in this study came from a very poor socio-economic background living in crowded urban, semiurban and slum areas. The study in Ghana previously mentioned also revealed a similar scenario where $93 \%$ of the pregnant women live and work in areas where the facilities for sanitation and water supply were inadequate. ${ }^{16}$

This study revealed that all pregnant women had clinically detectable jaundice, $51 \%$ had temperature $\geq 99^{\circ} \mathrm{F}$ and $38 \%$ had palpable liver. Extensor plantar reflex was present in 55\% cases and $27 \%$ had flapping tremor. Acute hepatic failure was detected in $56 \%$ pregnant women. A study was conducted in Guangdong Province, China among pregnant women with FHF revealed $100 \%$ patients were icteric, $24 \%$ had fever and features of AHF was detected in $76 \%$ cases. ${ }^{18}$ Another study in Mumbai, India detected AHF in $30.7 \%$ pregnancy with hepatitis E. ${ }^{19}$ A large prospective study from Northern India found that AHF was more common among HEV-infected pregnant women $(55 \%)$ and this finding was quite similar to our study. ${ }^{15}$

In this study, the mean value of serum bilirubin, ALT and PT was $11.62 \mathrm{mg} / \mathrm{dl} \pm 8.01 \mathrm{SD}, 777.75 \mathrm{U} / \mathrm{L} \pm 590.39 \mathrm{SD}$ and $29.88 \mathrm{sec} \pm 12.54 \mathrm{SD}$ respectively. Biochemical evaluation was observed in the study conducted in Mumbai previously mentioned and found that the mean value of serum bilirubin, ALT and PT was $12 \mathrm{mg} / \mathrm{dl}, 882 \mathrm{U} / \mathrm{L}$ and $24 \mathrm{sec}$ respectively among dead pregnant women with AHF due to HEV and these values were $11.5 \mathrm{mg} / \mathrm{dl}, 420 \mathrm{U} / \mathrm{L}$ and $8 \mathrm{sec}$ respectively among surviving pregnant women. ${ }^{19}$ Study conducted in Guangdong Province found the level of serum bilirubin, ALT and PT was $403.11 \pm 162.32 \mu \mathrm{mol} / \mathrm{L} \quad(23.57 \mu \mathrm{mg} / \mathrm{dl})$, $424.05 \pm 285.12 \mathrm{U} / \mathrm{L}$ and $43.93 \pm 43.66 \mathrm{sec}$ respectively. ${ }^{18}$

Wide and variable death rate was observed in pregnancy with HEV in different studies. In this study, the death rate was $43 \%$. A previously mentioned study from Northern India found a similar data $(41 \%) .{ }^{15}$ Slightly higher death rate $(54 \%)$ was observed in the study conducted among AHF cases in Mumbai. ${ }^{19}$

Conclusion: There is no current recommendation for termination of pregnancy with HEV in AHF. Hemodynamic instability, hemostatic defects in a critically ill AHF patient discourages the surgery. Provision of safe drinking water and 
proper disposal of sanitary waste as well as better personal hygiene can ensure a HEV free safe pregnancy.

\section{References:}

1. Purcell R, Emerson S. Viral hepatitis. In: Mandell GL, Douglas RG, Bennett JE, Dolin R, eds. Mandell, Douglas, and Bennet's Principles and Practice of Infectious Diseases, $6^{\text {th }}$ edn. New York: Elsevier/Churchill Livingstone, 2005: 2204-17.

2. Hussaini SH, Skidmore SJ, Richardson P, Sherratt LM, Cooper BT, O'Grady JG. Severe hepatitis E infection during pregnancy. Journal of Viral Hepatitis 1997; 4(1):51-4.

3. Kar P, Jilani N, Husain SA, Pasha ST, Anand R, Rai A, Das BC Does hepatitis E viral load and genotypes influence the final outcome of acute liver failure during pregnancy? The American Journal of Gastroenterology 2008; 103(10):2495-501.

4. ICDDR, B. Outbreak of hepatitis $\mathrm{E}$ in a low income urban community in Bangladesh. In: Health and Science Bulletin (English) 7(3) 2009 [online].Available at: http://centre.icddrb.org/pub/publication.jsp?classificationID $=56 \& \mathrm{p}$ $\mathrm{ubID}=10467$.

5. WHO. Hepatitis E. In: Fact sheets, Revised January 2005[online]. Available at: http://www.who.int/mediacentre/factsheets/fs280/en/.

6. Beniwal M, Kumar A, Kar P, Jilani N, Sharma JB. Prevalence and severity of acute viral hepatitis and fulminant hepatitis during pregnancy: a prospective study from north India. Indian Journal of Medical Microbiology 2003; 21: 184-5.

7. Medhat A, el-Sharkawy MM, Shaaban MM, Makhlouf MM, Ghaneima SE. Acute viral hepatitis in pregnancy. International Journal of Gynecology \& Obstetrics 1993; 40: 25-31

8. Tsega E, Krawczynski K, Hansson BG, Nordenfelt E. Hepatitis E virus infection in pregnancy in Ethiopia. Ethiopian medical journal 1993; 31: 173-81.

9. Strand RT, Franque-Ranque M, Bergstrom S, Weiland O. Infectious etiology of jaundice among pregnant women in Angola. Scandinavian Journal of Infectious Diseases 2003; 35: 401-3.
10. Kumar A, Beniwal M, Kar P, Sharma JB, Murthy NS. Hepatitis E in pregnancy. International Journal of Gynecology \& Obstetrics 2004; 85: $240-4$.

11. Patra S, Kumar A, Trivedi SS, Puri M, Sarin SK. Maternal and fetal outcomes in pregnant women with acute hepatitis $\mathrm{E}$ virus infection. Annals of Internal Medicine 2007; 147: 28-33.

12. Singh S, Mohanty A, Joshi YK, Deka D, Mohanty S, Panda SK. Mother to child transmission of hepatitis $\mathrm{E}$ virus infection. Indian Journal of Pediatrics 2003; 70: 37-9.

13. Jaiswal SPB, Jain AK, Naik G, Soni N, Chitnis DS. Viral hepatitis during pregnancy. International Journal of Gynecology \& Obstetrics 2001; 72: 103-8.

14. Khuroo MS, Kamili S. Etiology, clinical course and outcome of sporadic acute viral hepatitis in pregnancy. Journal of Viral Hepatitis 2003; 10: 61-9.

15. Navaneethan U, Al Mohajer M, Shata MT. Hepatitis E and pregnancy: understanding the pathogenesis. Liver international 2008; 28(9):1190-9.

16. Adjei AA, Tettey Y, Aviyase JT, et al. Hepatitis E virus infection is highly prevalent among pregnant women in Accra, Ghana. Virology Journal 2009, 6:108

17. Khuroo MS, Teli MR, Skidmore S, Sufi MA, Khuroo MI. Incidence and severity of viral hepatitis in pregnancy. American Journal of Medicine 1981; 70: 252-5.

18. Li X, Ma L, Yang Y, Shi Z, Zhou S. Clinical characteristics of fulminant hepatitis in pregnancy. World Journal of Gastroenterology 2005; 11(29):4600-4603.

19. Banait VS, Sandur V, Parikh F et al. Outcome of acute liver failure due to acute hepatitis $\mathrm{E}$ in pregnant women. Indian Journal of Gastroenterology 2007; 26:6-10. 